\title{
Values and science: an analysis the ethics in the science
}

\begin{abstract}
Science as a human activity relates to different human values, and therefore it is capable of ethic valuation, both for its consequences, as for its process and its action. For this reason, ethics cannot be separated from the scientific analysis, as the inherited conception pretended. It is necessary to research and know the different reasons of scientists to carry out some research or other. Scientific practice is social responsibility, and a scientific should not adopted behaviors contrary to that responsibility, because it can produce unintended consequences. This article aims to analyze how in the scientific activity the ethic should be the main thing.
\end{abstract}

Keywords: science, scientific practice, research, sociology, science, philosophy
Volume 2 Issue 3- 2018

Jesús A Valero Matas

Department of sociology, University of Valladolid, Spain

Correspondence: Jesús A Valero Matas, Department of sociology, University of Valladolid, Campus de la Putera Avda de Madrid, 50 34004Palencia, Spain, Tel 34979108252,

Email valeroma@soc.uva.es

Received: March 16, 2018 | Published: June 20, 2018

\section{Introduction}

During decades it has been accepted the fact that science consisted exclusively of knowledge and it was free of values, as the neopositivists and empiricism sustained. These schools were making a clear difference between fact and value judgements, in which science was reserved for fact judgements, despising any value judgement in scientific activity, as Ayer wrote science never disputes about matters of value, only about matters of facts. ${ }^{1}$ Later on, Ayer attests that moral judgements are not actual judgements; it doesn't mean that they are not important or that adducing arguments in their favor is impossible, but that these arguments don't work as logic or scientific arguments. ${ }^{2}$ In terms of Ayer's positivism, the exclusion of values of any analysis and intervention in science is clear, escaping from the unique analytic statements, capable of truthfulness or falseness, and consequently, values correspond to expressions of feelings and have no scientific meaning.

Towards the 40's of the XX century, science's mythologization, defended by the logic positivists and empiricist, started to weaken and new tendencies began to surmise, tendencies that were trying to break that separation between facts and values, giving way to a new theoretic analysis. One of the first theorists in trespassing the neo-positivists' theoretic threshold was R.K. Merton, opponent of the separation fact/value, defending the existence of values in science; epistemic, methodological, institutional, etc. In his exposition he indicated that science is a misleading word that refers to a variety of different things yet related among themselves. It is usually used to show:

a) a set of characteristic methods by means of which knowledge is certified

b) a stock of accumulated knowledge stemming from the application of these methods

c) a set of cultural values and morals governing the activities termed scientific any combination of the foregoing. ${ }^{3}$

It is on the third item where Merton emphasizes the science's values signification as valuation instrument within the scientific activity. This whole of moral imperatives will be called ethos of science. Although he didn't approach to epistemic matters-later in time Laudan ${ }^{4}$ will talk about epistemic values - his analysis of science highlighted the non-separation between fact and value judgements, sustained by both the philosophic and sociological traditions. ${ }^{5}$ The Mertonian analysis provided the sociology of science with two basic matters: the first one that science is not only knowledge, but also norms and values, as science has at least epistemic and institutional values. Secondly, the Mertonian thesis breaks with science's neutrality, as they depend on the process of investigation of the institutional and social context, and vice versa, that results in a preoccupation for the values in science. However, Merton's contribution, although now lying relegated to historic reflection, opened the door for the sociology and philosophy of science to a new reflection about science-the values.

From the philosophy, and following some of the Mertonian assumptions, as the negation of the dichotomy of facts and values, we find Bunge. This author, unlike the sociologist, carries out a differentiation a priori important, as he considers scientific knowledge to be ethically and axiologically neutral. ${ }^{6}$ In principle, admitting this consideration is going back to the inherited conception, as it accepts that knowledge itself is not susceptible of ethical valuation, yet knowledge abandons that ethical neutrality, when science applies, because it goes outside of the scientific knowledge's field, Science abandons ethic neutrality when it no longer studies natural phenomena, but bio psychosocial objects, such as people's needs, wishes and ideals, and also the means to satisfy ones and the others. ${ }^{7}$

For finally to end saying that, in conclusion, science, as a whole, is not ethically neutral. The thing is that its moral code does not coincide with the one imposed by nowadays societies: its strict moral code is Enlightenment and autonomous, meaning that it derives directly from its own activitiy. ${ }^{8}$

The reflection about the existence or lack of values doesn't stop there, it is quite more prolific. It has led to the appearance of two different theoretic models in the comprehension of values of science: internalist and externalist. The internalist approach analyzes the process from the inside, where it highlights the existence of a vast whole of epistemic, cognitive, methodological and other values, considered typical of science. Whereas, the externalist conception elaborates on its scope, and understands scientific tasks as just another human activity, as it studies and evaluates the involvement science has on the social plane: environment, biotechnology, cybernetics, etc. The 
internalist perspective centers its objections on the epistemic values, knowledge advance or application. It does not reject the intervention of ethical values, related to choosing the aims to reach, and neither in the selection of proposed hypothesis with the purpose of reaching the goals, and they state that there are different values that take part; however these will be conditional on cognitive values. When scientists choose a research line, it must be based on the values accepted by the scientific community. As Laudan wrote:

\section{One can argue against an aim basing it on the fact that}

1. it is utopian or impossible,

2. that it is incompatible with the implicit values of communitarian practice and with discernment that we usually accept. ${ }^{9}$

Cognitive values are the real devices of scientific knowledge, as they will put the basis for the methodological choice, as the cognitive values will affect scientific rationality, and based on this, scientists will choose the most adequate ways of achieving the aims proposed for the research. In short, for Laudan, the most favorable way to improve scientific process is, undoubtedly, the analysis from an internal perspective, and accepting an interference of outside values, implying straining knowledge's rational process. This is understandable if we do it from the first theoretic frame realized by Laudan, the pragmatism.

Defending this internalist approach, rejecting the interference of external values in the valuation about acceptance or rejection of theories, facts, hypothesis, etc., we find Rescher'sx thesis. Apart from defending that is the justification of the internal reality of science that makes the advance of knowledge possible, he also believes that autonomy and self-sufficiency give reality to the internal value of science. ${ }^{10}$ For Rescher, scientific thought cannot go out of itself to compare the different hypothesis or theories, nor real life results. Internal thought has its own rules and mechanisms of internal correction and leaving scientific knowledge at external comparisons' discretion would mean losing science's typical freedom. He points out before this: There are no feasible external criteria by which the science's results can be estimated. We don't have another alternative than to follow science wherever it takes us. There is no other external cognitive resource to supervise its operations. ${ }^{11}$

By saying this, he rejects any external interference in scientific tasks, as nothing coming from the exterior could be apex of control of internal science labor. So, it brings up a teleological vision of knowledge, not as output but as instrument of value. There is nothing above knowledge; knowledge itself is its own control instrument. The acceptability of scientific designs is something that has to be completely settled in keeping with the internal considerations of scientific tasks. A "science" subjected to external correction criterion simply doesn't make itself worthy of that name. Scientific affirmations, if corrected, they must be reformed by new scientific thesis. This fundamental fact is the living rock that provides the only base on which the doctrine of science's self-sufficiency can find its firm basis. ${ }^{12}$

Therefore, this conception limits the field of accuracy or error criterion to the science's internal structure itself, and the acceptance values of the scientific community. They don't consider that science is part of a social construct that depends on various contexts: social, cultural, economic, etc. Although scientists fundamentally look for the satisfaction of their individual needs, they also cast their scientific interests in society, how they affect, produce and favor it. At least applied science depends ion pictures from the outside. The externalist perspective doesn't reduce the analysis of science to scientific tasks but expands its investigation field to social values that interfere in the determination and valuation of science as a product. This interweaving of science and society implies that different externalist tendencies have appeared, that bring closer the reality of science to the social view through cultural interpretations. As Lindee ${ }^{13}$ point out, these interpretations of science that come from the different ways of examining scientific behavior are producing a comprehension of the wide cultural forces that influence both in science as in its popular appropriation. The examination of science from the externalist point of view doesn't consider scientific activity as autonomous and internally directed, but as an institution framed in an economic, political and juridical culture. Nelkin ${ }^{14}$ describes that the theoreticians that examine science from this perspective, are doing it expanding to other contexts, such as the political, juridical, economic field, the relationships between science and other social institutions, massmedia, religion, etc.

It is in the externalist conception where ethics examination acquires a major relevance in science. In this perspective the values of science interact with social values. Once again, we see that not all the theoreticians perceive science's behavior in its application in the same way. Following Mitcham's ${ }^{15}$ thesis there are three different approaches, although one of them presents a vision that is quite far from scientific practice, therefore it will not be taken into account. We will focus the analysis on the other two theoretical perspectives that have a bigger transcendence in the examination of scientific ethics from the sociological point of view; inside and outside. The "inside" orientation analyzes typical matters of scientific activity within the scientific community, as a subsystem. Once again, we follow the thesis of the sociologist R.K. Merton, and this way its orientation changes, as when science subjected to values is analyzed, the examination parameters are inverted, and what previously was an externalist interpretation turns into an internalist one. In this case, he centers his investigations in normative moral nature factors that rule scientific tasks, and that scientists internalize, as members of that system, making the advance of knowledge possible, such as: scientific honesty, universality, interchange, skepticism, originality, etc. ${ }^{16}$ but they also analyze the criterion used by scientists when choosing purposes and means, as they are submitted to beliefs, values, etc. In the same line we find Bunge' $\mathrm{s}^{17}$ thesis, that understands that science is a moral school, as it requires the acquisition or strengthening of a series of habits or normal attitudes: there is a corruption, as Bunge says, as it makes reference to a desideratum conjoint, and with the moral code of the scientific institution. This code complies with some precepts that are in part of ethical nature and at least of ethical extent.

At the beginning of the sixties of the last century the first tendencies disagreeing with "inside" interpretations appeared. Some of these reflections state that normative models develop an important role in the scientific community, but they are neither the only ones, nor they result fundamental when choosing or rejecting scientific paradigms; moreover, science not only circumscribes to values proceeding from scientific institutions, but there are also other subjacent in society. ${ }^{18}$ These will not be the ones having a major influence upon the "outside" thesis, but some public revelations, that took out some dishonest scandals, such as the Russian Lysenko's fraud. Matters like these and the different confrontations among scientists for discoveries' ownership, such as the confrontation between Gallo and Montagnier. ${ }^{19}$ During the eighties of the last century, they start to question the imperatives stated by Merton that during the Cold War served to justify many North-American scientific campaigns. These facts were 
casting doubt on the existence of an internal ethical code of science, and they were the main argument to disband the "inside" thesis for the "outside" ones. Then, some theoreticians started to investigate external factors that influenced scientific life, questioning the lack of interest, honesty or general interest of science, when scientist saw themselves influenced by external values, such as recognition, economic interests, the need to have institutional or private help in order to get the aims of their investigations among other things.

These social aspects have a significant influence in the scientists' behavior, but it also has repercussions in society, as their researches provoked many disasters, chemical wars, destruction of the environment, etc. We shouldn't forget that scientists are human beings and therefore as liable to be influenced as any other person, but competition and financing needs among other causes, made scientists become less and less unselfish, and fight for resources and demands from the outside. These matters make the scientist partly dependent on the outside; however this doesn't imply that we should only analyze science's secrets only from an outside perspective. As Sánchez Ron points out, any predicament can have a strong influence on the direction of scientific investigation. I am not saying, no, that science is in the end a "merely social construct", nor that there isn't any important "internal logic" element in scientific development, logic that promotes some directions or subjects and holds up others. What I am saying is only that the availability of financing resources is a very important element for the advance of science, and therefore, the history of science cannot be read or reconstructed without taking into account the social, political and economic history. ${ }^{20}$

Without any doubt, one of the themes of most interest in scientific ethics is found in the researches about human nature, and above all, those coming from biotechnology or biomedicine. We get into a matter where values cannot be seen inside nor outside, but it has to be examined combining both perspectives, as in scientific activity there is reciprocity of values that come outside from the inside and vice versa.

\section{Scientists' responsibility}

When talking about responsibility we perceive the reality of realness, and so it is not a matter concerning only ourselves, but it is an experience that appears from us or comes from the outside, and whose satisfaction we are responsible of. Therefore, actions will be correct or incorrect if they comply with that responsibility. The criterions adopted when looking for responsibility are not based on the same principles, nor on the same contexts. Responsibility's peculiarity falls within the transformation of different phenomena into moral interpretations directed to action. But that responsibility that we take as reflection point is subject to responsibility for something and responsibility before somebody. There are many points in the Christian doctrine where invite to a moral behavior, about something and somebody. We find the first one in the genesis, when God, after Cain's misdeed against Abel, asks Cain: Where is your brother? And he answered: I don't know, am I my brother's guardian? From a similar reading we find the parabola of the sower in Lucas, in Mateo the parabola of talents or in Tobias. ${ }^{21}$ In all of them an attitude of responsibility with oneself and the others is administered, as the pursuit of some interests is stated, and secondly, the respect of some rules, that put limits to the interests.

The examples from the Holy Scriptures show different types of responsibility, inscribed in the same ethical value, the positive responsibility due to the other's preservation and responsibility towards the rules. Both are based on the reciprocity principle, protecting one another. Responsibility understood in these terms is valid as a guide for science and technology, as these two subjects cannot stay closed, because responsibility is an open value. It is open, as responsibility depends of various contexts, and for the peculiarity of human values. For example, within the juridical context, responsibility complies with some compensation criteria, in the moral domain it is on a different level, and it can be found in the rule described as supreme: don 't do to the others what you don't want them to do to you, responding therefore to a reciprocity criterion.

The point of departure in any responsibility relationship appears followed by moral responsibility, that places in its actions the exercise of freedom and personal commitment, that without any doubt are basic values in an individual's behavior, and, therefore, in a scientist. But these characters are part of any human activity and they must respond responsibly before the actions derived from it. We are no longer before ethically traditional models, but we move in dynamic ethical planes. As previously mentioned, the ethical activity in society depends on different and complex contexts, so when we talk about responding responsibly we cannot withdraw from parameters of the existing, but of the possible existing.

The moral action of or about something in general terms, does not allow the understanding of the behavior of responsibility built on traditional models, but we must go further, ${ }^{22}$ proposes, not interpreting the morel action in terms of compensation nor reciprocity. The development of science and technology has opened the way too much wider spaces; therefore we can no longer talk about compensation, and even less about reciprocity. In relation to compensation, it is impossible thinking about a correspondence of our actions. Reciprocity requires equality of parts, and in nowadays world we find a strong inequality, and among them there is the power. We cannot possibly ask for the same responsibility to the president of the United States as to the chief of the Massai tribe. The same way, it is illogical to ask the same responsibility to the scientist and the enterprise that commercializes CFC as to the individuals who use it, because among other things, they may not know the consequences derive from its use. Therefore, responsibility is directly proportional to the level of power and the knowledge that one has. In other words, we cannot withdraw responsibility to the simple field of actions; we must submit it to the reflection about what is to be carried out and the analysis of possible consequences. ${ }^{23}$

\section{Scientific responsibility-ethic responsibility}

When talking about responsibility from its social dimension, we usually refer to professional responsibility, for having come up from a pile of knowledge acquired through learning, that serves a cause in particular, and that generally brings a benefit for the human beings. Scientists and technologists are like bearers of this knowledge, and depending on the purpose of their actions, they acquire a responsibility to which they must answer with facts. From this action it can be deduced that on one side, scientific or professional responsibility comes from the specialized knowledge someone has, and on the other side, that this knowledge, when serving society, must prevent producing negative effects on individuals.

Taking this matter as a basis, it is convenient from the ethical point of view to make the difference between the demonstration context and the application context, as they don't imply the same values. For 
example, the process and consequences of a scientist who wants to get to know and discover cosmos doesn't imply social aspects, and even less it implies a risk for human life, in principle all the contrary, that is to say, it solves universe's mysteries. Things change when a scientist starts doing researches about human nature, for example, Develop the ones made by Wilmut and others in Roslin institute. Research may follow the same procedures ass in the previous example, what happens when this knowledge means cloning human beings? - at this point serious reflections about responsibility come up. While in the first model of scientist responsibility lies in choosing theories, spreading knowledge, i.e., demonstration of epistemic matters, and he/she must answer before the scientific community, in the second model the responsibility is before the human being and he/she must answer before the whole society. Therefore, the effects and consequences derived from the research will not have the same repercussions or the same effects, and this implies taking up again the Aristotelian theories and talk about the different responsibilities: poietic responsibility, practical responsibility and theoretical responsibility.

From the practical analysis and moral valuation, it is quite complicated imputing a responsibility to a scientist or technologist, as points out, risk is not produced by only one action, but there is a great number of agents-collective or individual-researchers, producers, consumers, institutions, organizations, etc., intervening in such a way that looking for responsibilities comes to be a complex task. On the other hand, with nowadays ethical debate model, imputing an ethical responsibility to an individual or research collective would be unfair, as, like Jonas writes, the modern technique has introduced actions of such a different magnitude, with such original objects and consequences, that ethic's frame cannot comprise them. We cannot hide this matter falling into the mistake of looking for responsibility in the old paradigm, as we are in a new situation, that has changed the old traditional models, imbuing us in a different paradigm, with new challenges and new risks. Jonas' words cast upon a new direction, however, Bechmann's contribution is more explicit, as starting from an uncertain frame, he gets to a complex situation looking for responsibilities, as science and technology overall have got the better of this ethical scenario, before the lack of predictability and the absence of individual agents. This makes him state that a moral founded on reciprocity and an ethic based on universality will justly fail before this social conflict situation and future expectation. Responsibility theory cannot be based on traditional positions, either the model of assistance of justification: anthropocentric responsibility, because it leads to questioning other types of life, or the model of reciprocity, that excludes unborn children, people with mental illnesses, and non-human living things. As a consequence, the new ethics must be enlarged, i.e., not subordinating nature to human caprice, nor looking at the immediate future only, but waiting for new possible worlds.

From this point of view, we think we must take into account, when valuing science and technology, the ethically correct purposes and the ethically adequate means. This will be fundamental because the ethic norms will establish intermediate ways in scientific and technologic action, but also because the complexity and secrecy some scientists and technologists use as a justification for their actions leads to discarding and excluding most of the society. With this, the individuals' level of participation is reduced, leaving the control of science and technology in the hands of politic, economic and other groups. Responsibility spaces are vague and they prevent from establishing some clear rules. In order to avoid this situation, it is convenient to take into account, when talking about responsibility, the proposals of action, measure the purpose of the practice of human actions, and the negative incidences in solving problems because omission.

\section{Inadequate behavior of scientists: ethical valuations}

Ever since the beginning of science, different causes of scientific frauds have been investigated, conscious or unconscious plagiary, errors or traps of any other kind. This has generated a certain social reticence regarding scientists' honesty, questioning the existence of an ethical code within the scientific community; and, as a consequence, made people wonder if scientists are really looking for the truth. These kinds of acts have increased society's skepticism towards science, and some theoreticians even accuse these scientists of consolidating the anti-science. Others, like Holton, state that fraud and tricks are part of the structure of scientific research itself. ${ }^{24}$

Going on with this line of analysis, and avoiding falling into interpretative slants about scientific activity, we must distinguish, on one hand, the analysis of epistemic and methodological representation that studies thoroughly the reflection upon the nature of truth, theory validity, etc., and on the other hand, science's social instrumentality. This doesn't imply the absolute differentiation of both aspects, but rather the evaluative description of different features in the investigation about science's sense as social phenomenon. This differentiation, from an axiological perspective, makes us consider the existence of a fundamental (nuclear) axiological code, common to all contexts that will serve as reference in the development, research, analysis and reflection of the different values that intervene in the various social domains. However, we will find particular axiological codes, that will meet internal valuing estimations, and in this particular case, the development of the scientific tasks. This fragmentation of values doesn't mean denying the concomitance relationship between science and society, on the contrary, it means deepening in matters that affect directly specific spaces where other values' incidence is minimal.

Focusing the analysis on ethics, it is important to point out that ethics is not a prescription. We must understand that ethics' aim is to find a sufficient reason for the moral form; if that reason must be expressed through a judgement with content, the content will be ethical and canonical, not moral and prescriptive. However, ethics have a normative value of temporal validity, i.e., expiring. ${ }^{25}$ With relation to this consideration and making a retrospective analysis, we can observe an expiry of the ethical values, ${ }^{26}$ ethics don't disappear but their canons change, transform and new values appear.

After this brief approach, we go on with the scientific dispute, and we try to investigate if it really constitutes an ethical transgression itself. Merton and others have investigated about this objection and have conditioned ambivalent behavior to the psychological truth rudiment, that surrounds the desire of individual satisfaction; they got to state that any "extrinsic reward - fame, money or positionis morally ambiguous and potentially subversive of the culturally estimated values, as when rewards are given, these may change the initial reason: the interest for recognition may ousted interest in favor of promoting knowledge". ${ }^{27}$ The social influence from this point of view is a component on which scientist's base so as to magnify their achievements, and this attitude not only produces a social disagreement, but it also generates internal disputes, making one doubt about the existence of normative values, as ethical values are adjusted to their own individual interests. In this social projection we find two quite spread behaviors, caused by the institution itself and that 
don't comply with the preestablished rules, such as the acceptation of theories, discoveries, etc., subject to authority principles; and secondly, the need to get into the group of notables of science. In the first case, accepting authority implies shaping values according to dominant tendencies, without justifying decisions to established principles, and drawing ethical consensus parameters, adjusted to power paradigms that irradiate negativity in science. In the second case, it is due to the wish of entering the group of notables of science, for the status, a matter backed up by the institution. Nevertheless, the scientific institution itself is the one that eventually detects frauds.

Throughout its history different confrontations have appeared among scientists, either for the ownership of a theory, or for defending a theory over another. This was the case of the well-known individual disputes between Newton and Leibniz, or between Newton and Hooke, as well as the ones held among the members of a family, as it happened with Bernoulli brothers, among others; all of them ended in favor of the one who had a better position in the scientific community. In other cases, the persistence of the validity of a discovery was due to authority criterion, without having been evaluated, as Piltdown's ${ }^{28}$ fraud. Its applicability was prolonged for nearly forty years, thanks to his mentor's, Woodward, geological preserver of the British Museum, authority.

Another dysfunction in science domain can be found in the scientific frauds, as in Summerlin's ${ }^{29}$ case, who justified his action with the help of his feeling of failure. With the intention of avoiding frustration, he decided to paint white the back of a mouse: his fraud was discovered after some time. It wouldn't be the last farce the scientific community would have to deal with, as some years later another similar case come through: a medical researcher from Harvard, Darse, falsified laboratory information and, as it happened with Summerlin, the falsehood was once again exposed. In some cases, there is a help based on authority. These researchers were working with notable scientists and in important research centers, therefore there was a goal behind it, getting fame. Something that the institution itself promotes.

In this same line of improper behavior, we find the ones manipulating information, as it happens many times, when scientists choose data that doesn't adjust to the scientific method, so as to fulfill the wished aims, although in this case facts might or might not be done on purpose. If we consider the matter regardless of the model's typology, in these cases there has been a violation of the ethical norms, and if they were not frequent, they are clearly prejudicial for science. From the sociology of science, we find different controversies, and nowadays we are confronting one of the most complex problems, opened by some ramifications of the sociology of science against methods and procedures of traditional sciences. There are two essential arguments in this confrontation, that started the well-known "science wars", not as much because of the intrinsic nature of the process, but for the application context, where those "wars" take place. On one hand, in the first argument we can notice an excessive use of scientific, i.e., appealing to the authority of science as a dogma in order to justify the analysis' veracity. With the aim of avoiding this theoretical disagreement it is necessary to accept that science is part of society, but it is neither the only element inhabiting in it, nor many social keys can be determined by science, therefore science cannot be conceived as "creating". The second argument contains the mistake of taking scientific statements out of context, so as to give validity to other theoretical spaces, formulating pseudo-scientific statements and, consequently, creating certain pseudo sciences. This interpretation causes falling into indignity, as it gives priority to individual principles, disfavoring the collective ones, and projecting it farther, it leads to slowing down knowledge's advance. ${ }^{30}$

The lack of internal coherence within these theoreticians of social science's thesis has worsen the eternal problem of confrontation between social and natural sciences, to the point that some of the theoreticians of hard or semi-hard sciences have started to take severe dialectic measures against sociologist discourse. This fact provoked an accusation crossing in scientific magazines and books concerning the matter.

The first important polemic appeared in 1994, when Gross and Levitt, in their work Higher Superstitions: The Academic Left and Its Quarrels with Science ${ }^{31}$ promoted a campaign against the social studies of science. Among their multiple accusations, they emphasized the indiscriminate use of metaphors of science in social studies, as a means of giving validity to theories or social models. However, these were not the only studies recriminating the appearance of writings against the social studies of science, for using scientific epistemology as a device for defending theories, without validity. The most virulent accusations came from Sokal and Bricmont in Impostures intellectuals, ${ }^{32}$ spilled their reprobation against certain social theoreticians, for their disproportioned use of scientific terminology and for building and using a dark and indecipherable language in some cases, and errors in the interpretation of theorems of physical-natural sciences, in others. One of the first people to be criticized was Lacan, whom they have censured for using, in a confuse and inexact way imaginary numbers, and for conferring scientific validity to psychoanalysis, ${ }^{33}$ producing darkness in his reasoning. The texts of the writers Deleuze and Guttari are even more incomprehensible. About these, Sokal and Bricmont state having "found a dozen scientific terms used without any apparent logic, and the discourse oscillates among absurdities (a function is a slow motion) and platitudes (science doesn't cease to foment accelerations)". ${ }^{34}$ This text is followed by a wide use of scientific terminology taken out of context and brought to a field that doesn't give any practical utility to the social reflection.

Without any doubt, most of the criticism takes into a chapter referred to epistemic relativism, where hard recriminations against Quine, Khun, Feyerabend and the Strong Program in the sociology of knowledge appear.

I humbly consider that, although most of their accusations have enough reason, the dialectic violence against these ways of thinking has been disproportionate, in spite of the vehemence in the elaboration of these theoretic models.

Accepting as valid such reflections means transforming in rational something a priori not rational, as epistemologically speaking, theories, aims, etc., must follow an internal logic, connected with some rational values, avoiding the emission of judgements that could be prejudicial for knowledge. With the purpose of avoiding this kind of report, Laudan ${ }^{35}$ suggests the need of rules confirmed by empiric observation that, in turn, will serve as confirmation or rejection instrument for other theories, although criticism shouldn't be exclusively centered on the epistemological perspective, as this type of discourse also affects methodological and educative fields. The inclusion reasoning defended by sociology, especially by methodological relativism or constructivism, does not develop a method appropriate to a reasoned argumentation, adequate and consistent, apart from the fact that its analysis transgresses the ethical value. And the fact is that this 
theoretical-methodological arrangement, instead of contravening strategies, it finally establishes a discourse based on absurdity as a method; as Cayetano López points out, "these confusions have devastating effects on the reasoning's rigor and the intellectual honesty of professors and researchers in various subjects. And the point is that the radical skepticism underlying in these theories always contains, as Bertrand Russell says, a frivolous insincerity element." ${ }^{\prime 36}$

Rereading López, and moving to the Kuhnian ${ }^{37}$ pedagogical context, we can observe that the thesis defended by these theories not only deny any normative imposition (Mertonian or any other), but they also generate an important ethical problem, leaving out one of the basic principles of science and other branches of knowledge: intellectual honesty; and this will affect significantly the analysis of science. ${ }^{38} \mathrm{Kuhn}$ was stating that "people who study science are discouragingly prone to receiving their teachers' and the texts' statements without questioning them"; ${ }^{39}$ and, connecting it with the analysis made by Echeverríaxl, where, apart from stating that "scientific education includes very varied actions", he also states that "however, we must distinguish between two basic actions, teaching and learning, that usually involve very specific human beings". We can deduct from here the importance ethics acquire in teaching science; and the fact is that the argumentation and spreading of wrong theories, or theories in which the searching of the truth is not implicit in their discourse, incur serious ethical problems for defending an abstract or external analysis to science.

Teaching and intentional education of a priory false theory will produce negative effects on students, and it will impede knowledge's advance, as instead of increasing truth and decreasing falsity, it will have the contrary effect. Moreover, getting back to Echeverría, we want to point out that "in order to understand a scientific statement, one must have learned complex knowledge, both theoretical and practical, without which it is not possible to discover, justify, and even less to apply science". ${ }^{40}$ Then we can question what criterion students could defend, if their education has been subjected to a theory inscribed in error, because, as relativists say, it is not so important knowing if what is being said is true or false but judging in which way social and political interests affect in the elaboration of theories.

In spite of not admitting that their theoretical approach doesn't have any scientific justification, in the design of this kind of conjectures there is a lack of ethical valuation, and they solve the problem resorting to Feyerabend's axiom "Everything is allowed" and describing science as a social construction. Moreover, theories that found their thesis on mere descriptions of politic or social interests lead to the spreading of theoretically authoritarian models, and they won't accept critical theories nor will they learn from experience, ${ }^{41}$ but they will introduce a new scientific culture founded on the Doxia and rejecting praxis. Therefore, we find ourselves before a fraud and ethical damage, both in the activity and in scientific action.

The criticism to this kind of conceptualizations doesn't mean at all reducing all the analysis of social and natural science to a mere epistemic or ethical determinism, because, as it has already been said, none of them excludes other values that interact with science, but they plead for establishing a flexible normative. Leaving out any type of rationality in science, far from the established models of scientific validity, means allowing non-rational conceptions to settle in the scientific world, without any kind of criticism nor rejection, and it represents the acceptance of the idea that all design and validity of theories withdraws from private or collective interests, built on power. For example, if a professor or researcher in physics thinks that the best solution for fighting against the deterioration of the ozone layer is throwing an atomic bomb, and to this opinion scientists and some public powers subscribe, then-accepting the constructivist' point of view, whom don't care about the criterion's truthfulness or falsity-as the controversy would be solved in favor of the bomb throwing, the next step would be spreading, showing and applying this solution, although it is completely absurd.

Delimiting the scientists' action starting from some institutional imperatives doesn't mean falling into a normative determinism, as the perceptive side doesn't impede making coherent, adequate and precise decisions. Let us not forget Merton's words "The authority borrowed from science turns into a powerful symbol of prestige for antiscientific theories". ${ }^{42}$

\section{The need of an ethics in scientific activity}

Science is product of a pile of knowledge, as consequence of collective actions. Although many scientists developed their activity individually, they needed their predecessors' theoretical-practical studies in order to achieve their aims in their researches or discoveries, therefore, science could and can advance in knowledge thanks to interchange and spreading. If Gauss wouldn't have had information of his predecessors' discoveries and theoretical developments, he could have hardly formalized the curve, law, theorem and approximation that have his name. This interchange of knowledge not only contributed to making it easy for scientists to enter a communication and collective collaboration process, but it has also affected other research spheres and it produced changes in social and scientific behavior. ${ }^{43}$

From the sociological analysis, we cannot leave out the relationship between science and power, either economic, political or military; ${ }^{44}$ and in the last decades of the $20^{\text {th }}$ century, these connections have reached unthinkable levels. Throughout history, knowledge has been coveted by politicians, businessmen and governing, as it was an instrument of power, like it happened with the discovery of gunpowder, shooting weapons, atomic bombs, missiles, etc. Scientists and researchers have not stayed far of these private ambitions; their abilities and skills were important for businessmen and industrial as it brought a stronger control capacity, and also very big economic benefits. After some time, scientists understood that the economic and social registers could bring them excellent sinecure, so some of them decided to abandon the academic field. In the second half of the last century, important groups of scientists, seduced by money, fame and business, abandoned the academy for turning into businessmen or managers of knowledge goods, transforming it from a cultural value to a material value.

Nowadays we are living emerged in a world on constant knowledge advances, and overall, we find ourselves before more and more complex moments of science, both because the polemics produced within the scientific community, and because for the effects derived from the application of certain scientific advances (techno scientific) in society. The interconnection between science and technology has made the scientific (techno scientific) process more complex and it has sharpened the ethical problems. At the half of the past century, new technologies have produced hard ethical confrontations among science, technology and society, and nowadays we are in front of a new era, conquered by molecular biology and biotechnology; and, because of its basis, intrinsically related to human nature, a new ethical problem between science and society has arisen.

Science, scientists and techno scientists have the obligation, because of their involvement in knowledge fields, to start the search 
for the truth; and, as individuals, they must control that science doesn't destabilize society, and for their knowledge not to be used with damaging purposes. This mission is problematic for the scientific community, because it is formed itself by individuals whose actions and decisions will be conditioned by social values; but, as they are helped, favoring their researches, they have the responsibility not only to favor progress, but also to teach, spread and evaluate all the beneficial and pernicious effects of their research.

Worldwide society is at a crossroads, and with a highly dangerous future, if ethical rules are not imposed for certain researches. The genome project could be an example of how the development of certain projects functions. Since its beginnings, ${ }^{45}$ with public funds from several countries, it has been submitted to a never-ending debate. In the beginning, it only arouses interest within public research; however, as it advanced, some problems appeared among some researchers. The same happened to Venter, that a priori didn't want to go into the businessmen scientists' group, however he focused on business as he tried to patent his discoveries. The denial made him detach from the project, and make an alliance with pharmaceutical industries, with a clear mercantile aim. Then, the pharmaceuticals started to get interested in the project, as it produced great economic dividends, and they started their own private researches in parallel. This way, something that started initially as a general good has turned into private business. Venter and his partners have patented part of their researches, and the worst is that one must pay in order to get to them, while they have used public researches for free.

The cloning case has a major transcendence because of the consequences of its application upon human race. When Wilmut and his partners have created Dolly sheep, Pandora's Box has opened: with it, a new scientific research field was opening, but it also generated a new socio-scientific problem. Wilmut himself wrote that "human cloning is now in the specter of future possibilities, and we, more than anybody else, contribute to place it there. We wish it wouldn't be this way, but there it is and it will go on there as long as cloning lasts". ${ }^{46}$

Regarding this fact, the scientific community is facing a new challenge: if animal cloning conveys human cloning. Cloning must not be seen as something pernicious; in many cases it is an excellent instrument to solve some human problems and improve life quality. However, everything that seems to be socially perceived about cloning is its possible inadequate use in the field of human race; nevertheless, nobody speaks about its benefactions when used therapeutically.

It can't be forgotten that in science, as in other knowledge spheres, we will encounter problems and uncertainty, and with it, risks. Medical research could be the one where there has been a major consensus, but it doesn't mean that there haven't been any confrontations. Since some time ago there have been protests against experimenting with animals, or xenotransplants, ${ }^{47}$ with limited repercussions, due to a favorable internationalization of society. However, there isn't the same mood in the genomic research and cloning, where we find more difficulties and important controversies, both among scientists and in society. Cloning with therapeutic purposes is defended by an important percentage of scientists, intellectuals and society, as the theologist Küng points out: I'm seriously worried that people would try to build a new human being, without meaning to help somebody, but out of the mere greed of creating artificially a better human being, ${ }^{48}$ however it shelters Frankenstein phenomenon. Somehow, the way he superfluously analysis the value of cloning or that of genetic research, it could be that we are not only before the Frankenstein syndrome, but, as Haraway ${ }^{49}$ says, we are getting closer to the Cyborg model. This matter is not unfeasible at all, as we already are before the possible election of individual's à la carte, product of evolution and biotechnology, and because of the economic interests it may give to the medical and pharmaceutical industries.

The appearance of ethical reflections is indispensable for scientific knowledge; however, it must not stop science's (technoscience's) aims, i.e. searching for the truth, discover and get to know the unknown. In all this process, one must not forget that in the advance of science there is a responsibility compromise that prevents from trespassing some ethical limits. Another matter that represents great expectations for the human being is the research with trunk cells $;{ }^{50}$ however, its practice has also set an alarm for its possible inadequate use. The problem lies in not respecting various moral rules, and that some researchers could start projects not too positive for society or that the economic need could end could get in control and lead to being the only one in charge of future decisions.

With these referents, we need to solve this matter from the ethics, as in fact it is built upon moral values. The problem lies in how to present the ethical norms as to create order, without trespassing the frontiers of undesirability, although we are submitted to knowledge's advance. Regarding this matter, Wilmut stated: "As scientists, closer to action than any other people, we feel obligated to expose facts just as we see them and as clearly as we can, because facts cannot be allowed to determine ethics (not equivalent to duty), they have a lot in common with moral arguments, in many different points of view". ${ }^{51}$

This doesn't mean rejecting knowledge's nor scientific research's advance, but the contrary. From here research is helped, but not at any price, the scientific community, politic and economic forces among others must establish some limits. These frontiers get to establish an ethical model that regulates scientific activities that must be respected by all the parts involved and the ones controlling power and economy shouldn't skip the model when it goes against their private interests. With this, a global ethical model is not the one that it's promoted, as Küng ${ }^{52}$ proposed, but entering a reflexive and open ethical debate, limiting however those improper and undesirable activities.

Küng's proposal has been formulated in other terms by Ape. ${ }^{53}$ This philosopher's proposals have alerted various politic, scientific, religious, etc. sectors, that were considering it unfeasible and even heretic. Apel however didn't mean it to be so, he was only calling people's attention upon the abuses of science and technology, and that beneath the discourse about technological advance there were perverse effects. Apel's contributions, subscribed some time later by social and natural theoreticians, have opened the debate again-if it was ever closed-, exposing that if science and technoscience have a global scope, why a global ethics shouldn't be possible. Apel's proposal, far from seeking happiness, was trying to make the process of global ethics take into account the interests of all the individuals, and not only those of few of them, and of course, those of science and technology. Küng's proposal follows other paths, but they both have the same final point, a common fundament of values and rules, rights and duties, i.e., a common ethic attitude. ${ }^{54}$

From the axiological point of view, ethics are just another value, although from the social parameters it is a dominant value, as society estimates its development as a principle that protects individuals from external abuses or threats, all juridical, military, etc. In this situation, we are facing two contexts, the social and he scientific one that are also influenced by sub-contexts. The complexity lies in implementing these contexts without transgressing any internal rules of each of them, but also without breaking general norms. Going on with this idea and 
knowing that we are moving among systems and subsystems-each of them with plural normative parameters, we consider adequate developing a model without any dominant value, but with many values. The combination of these values will respond to the needs of some cellular values, that leads to creating a nuclear normative model, based on a general ethical norm, and leaving space for an adjacent normative ethos, adjusted to each context. This way we can direct peripheral values toward nuclear values, without corresponding to an omission of principles ordered in favor of a social balance. This doesn't mean that ethics are founded as a dominant value, nor it is pretended; its function will have the appearance of a horizontal value, to which values will appeal for advice, not because they have to. This pretends avoiding facts to determine ethics, and also ethics to determine facts. ${ }^{55}$

Taking again normative science is not necessary, as, although certain imperatives are still active, the institution's condition is not only promoting knowledge, but it also must, from axiological, methodological, epistemic, etc. ${ }^{56}$ plurality, humanize scientists and their science, so as they don't get to fall into dehumanization for a bunch of temporary values. These social, cultural, economic, etc. alterations have also brought with them a transformation of the human beings that are more and more at the mercy of scientific experimentation. People talk nowadays about scientific and technological dehumanization, consequence of the obsession to get eternal longevity, and human perfection lies in it. It doesn't seem very far, now when we can choose biologically perfect human beings, and some scientists say that someday we will be able to connect to human minds. Before this probable reality, we should ask ourselves until which point should man and science get. ${ }^{57}$ If we go on with the Greek sin of arrogance, we will be able to state that mankind will get to absolute knowledge and therefore they will control nature, as Greeks and some contemporary scientists wished, but too much supposing. ${ }^{58-60}$

Going on with Sloterdijk's hyperpolitic ${ }^{61}$ proposal, there is an inkling of hope left, on which global spaces can be built to pressure and make public powers adopt seriously an ethical attitude, applicable to all mankind, so that we don't get to start potentially undesirable actions; instead of discussing about creating artificial, genetically and psychologically controlled human beings, let's talk about healthy and technologically advanced human beings. ${ }^{62}$

\section{Acknowledgements}

None.

\section{Conflict of interest}

The author declares that there is no conflict of interest.

\section{References}

1. Ayer AJ. Language, Truth and Logic. London: Penguin; 1971. 208 p.

2. Agazzi E. Right, Wrong and Science: The Ethical Dimensions of the Techno-scientific Enterprise. Amsterdam: Rodopi; 2004. 354 p.

3. Apel KO. Towards a transformation of philosophy. London: Routledge \& Kegan Paul; 1980. 308 p.

4. Laudan L. Science and Values. The Aims of Science and their Role the Philosophy Debate. Berkeley: The University of California Press; 1984. $160 \mathrm{p}$.

5. Barnes B. Interests and the growth of knowledge. London: Routledge; 1977. $128 \mathrm{p}$.

6. Broncano F. Mundos artificiales: Filosofia del cambio tecnológico. México: Paidos-UNAM; 2000. 328 p.
7. Bunge M. Pseudociencia e ideología. Madrid: Alianza; 2013. 252 p.

8. Barnes B. About science. Oxford: Blackwell; 1985. 163 p.

9. Bunge M. Crítica de la nueva sociología de la ciencia. Buenos Aires: Laetoli; 2015. 209-214 p.

10. Collins HM. And Empirical relativist programme in the sociology of scientific knowledge. 1983 Science Observed: New Perspectives on the Social Study of Science. London: Sage Publ. Co; 1983. 263 p.

11. Cortina A. Ética mínima. Introducción a la filosofia práctica. Madrid: Tecnos; 2003. 304 p.

12. Echeverría J. Introducción a la metodología de la ciencia: La filosofía de la ciencia en el siglo XX. Madrid: Cátedra; 1999. 344 p.

13. Echeverría J. Ciencia y Valores. Barcelona, Destino; 2002. 312 p.

14. Feyerabend P. Against Method. New York: Humanities Press; 1975. 336 p.

15. Mitcham C, Briggle A. Ethics and Science: An Introduction. Cambridge, Cambridge University Press; 2012. 388 p.

16. Feynman RP. What do you care what other people think?: further adventures of a curious character. London: Unwin Hyman; 1988. 256 p.

17. Feynman RP. The Meaning of It All: Thoughts of a Citizen-Scientist. Newyork: Perseus publishing; $2007.133 \mathrm{p}$.

18. Fleck L. Genesis and Development of a Scientific Fact. Chicago: The University of Chicago press; 1986. 222 p.

19. Gardner M. Science: Good, Bad, and Bogus. NY: Prometheus books; 1989. $429 \mathrm{p}$.

20. Gieryn Th F. Relativist/Constructivist Programmes in Sociology of Science: Redundance and Retreat. Social Studies of Science. 1982;12: 279-297.

21. Gribbin J. Science. A History, 1543-2001. London: Allen Lane; 2002. $647 \mathrm{p}$.

22. Gross PR, Norman Levitt. Higher Superstitions: The Academic Left and Its Quarrels with Science. Baltimore, John Hopkins University Press; 1994. $328 \mathrm{p}$.

23. Hixson J. The Patchwork Mouse. Garden City: Anchir Press; 1976. 228 p.

24. Huber, Huber BL. El reloj de la vida. Barcelona: API-España; 2003. 197 p.

25. Ibarra A, Lopez Cerezo JA. Desafios y tensiones actuales, en ciencia, tecnología y sociedad. Madrid: Biblioteca Nueva; 2001. 320 p.

26. Kohn. False Prophets: Fraud and Error in Science and Medicine. London: Blackwell Publishers; 1988. 250 p.

27. Kuhn. The structure of scientific revolutions. Chicago: University of Chicago Press; 1975. 264 p.

28. Kuhn T. The essential tension: selected studies in scientific tradition and change. Chicago: University of Chicago Press; 1966.390 p.

29. Kurtz P. Science and Ethics: Can Science Help Us Make Wise Moral Judgments?. Amherst: Prometeus Books; 2015. 359 p.

30. Kusch M. The Sociology of Philosophical Knowledge. Dordrecht: Kluwer; 2000. 123 p.

31. Latour B. Pandora's hope: essays on the reality of science studies/ Cambridge, Mass. London: Harvard University Press; 2001. 3-20 p.

32. Latour B, Woolgar S. Laboratory life: the construction of scientific facts Princeton. NJ: Chichester: Princeton University Press; 1986. 296 p.

33. Laudan L. Beyond, Positivism and Relativism. Theory, Method and Evidence. Boulder: Westview Press; 1996. 288 p. 
34. López C. El dislate como método, en Claves de razón Práctica. UK: ${ }^{0}$ 92. 1999. $192 \mathrm{p}$.

35. Merton RK. The Sociology of science. Chicago: The University of Chicago; 1973. 636 p.

36. Merton RK. Science, technology \& society in seventeenth century England. New York: H Fertig; 1970. 279 p.

37. Merton RK. Social theory and social structure. New York: Free Press; 1968. $423 \mathrm{p}$.

38. Mosterin J. Conceptos y teorías en la ciencia. Madrid: Alianza; 2000. $376 \mathrm{p}$.

a. Nagel Th. The Last Word. Oxford: Oxford University Press; 2001.149 p.

39. Newton Smith W. The Rationality of Science. London: Routledge \& Kegan Paul; 1982. 306 p.

40. Olivé L. El bien, el mal y la razón. México: Paidos-UNAM; 2000. 56-61 p.

41. Pickering A. Science as Practice and Culture. Chicago: University of Chicago; 1992. 482 p.

42. Popper K. The Open Society and Its Enemies. London, Routledge; 2017 $760 \mathrm{p}$.

43. Popper KP. The Poverty of Historicism. London: Routledge; 2006.166 p.

44. Popper KR. Conjectures and Refutations: The growth of Scientific Knowledge. London, Routledge \& Kegan Paul; 2002. 582 p.

45. Putnam H. Meaning and the Moral Science. London: Routledge \& Kegan Paul; 1978. 154 p.

46. Putnam H. Reason, Truth and History. Cambridge: Cambridge University Press; 2012. 236 p.

47. Sánchez Ron JM. Los mundos de la ciencia, Madrid: Espasa; 2002. 328 p.
48. Sarton G. Introduction to the History of Science. Baltimore: The Williams \& Wilkins Company; 1950. 839 p.

49. Singer P. Animal liberation. New York: Ecco; 2009. 324 p.

50. Singer P. One world: the ethics of globalization. New Haven: Yale University Press; 2004. 272 p.

51. Singer P. In defense of animals. Oxford: Basil Blackwell; 2013. 347 p.

52. Sokal Bricmont JA. Intellectual impostures: postmodern philosophers' abuse of science. London: Profile; 1998.

53. Trocchio F. Las mentiras de la ciencia. Madrid: Alianza; 2002. 536 p.

54. Valero Matas JA. Sociología de la ciencia. Madrid: EDAF; 2004. 338 p.

55. Valero Matas JA, Coca JR. Epistemología y hermenéutica de la ciencia. Arbor. 2013;189(761):1-11.

56. Velikovsky I. Worlds in Collision. New York: Simon \& Shuster; 1977. $162 \mathrm{p}$.

57. Wilmut I, Campbell K, Tudge C. The Second Creation: Dolly and the Age of Biological Control. Cambridge: Harvard University Press; 2001. $338 \mathrm{p}$.

58. Willmott C, Macip S. Where Science and Ethics Meet: Dilemmas at the Frontiers of Medicine and Biology. Santa Barbara, CA: Praeger; 2016. $180 \mathrm{p}$.

59. Wolpert L. The unnatural nature of science. London: Faber; 2000. 201 p.

60. Woolgar S. Science: the very idea. Chichester: Ellis Horwood; 1988. 112-117 p.

61. Ziman J. Real Science: What It Is and What It Means. UK: Cambridge University Press; 2000. 412 p.

62. Zuckerman H. Deviant behavior and social control in science. In: Sagarin, editor. Deviance and Social Change. California: Beverly Hills; 1977. 87-138 p. 